DOI https://doi.org/10.18551/rjoas.2018-11.31

\title{
AREA MAPPING AND IMPLEMENTATION OF AGRICULTURE INSURANCE IN THE ORGANIZATION OF SUBAK IN BALI PROVINCE
}

\author{
Darmawan Dwi Putra*, Arisena Gede Mekse Korri \\ Agribusiness Study Program, Faculty of Agriculture, Udayana University, Indonesia \\ Utami Ni Wayan Febriana \\ Landscape Architecture Study Program, Faculty of Agriculture, Udayana University, \\ Indonesia
}

\author{
Gunadi I Gusti Alit \\ Agroecotechnology Study Program, Faculty of Agriculture, Udayana University, Indonesia
}

*E-mail: dwiputradarmawan@yahoo.com

\begin{abstract}
Development of agricultural insurance as a risk management strategy mechanism is complex. Conditions of farmers in Indonesia also became one of the causes difficult to build agricultural insurance as part of Indonesian agricultural development. Moral hazard in each individual farmer in Indonesia as well as every farmer in Indonesia is still not insuranceminded also be one of the causes. As a precaution against the possibility of crop failure that can occur in paddy rice farming, the government has launched a program of agricultural insurance in several regions in Indonesia which applied to paddy and the name of the program is the Rice Farming Insurance Program (RFIP). For information, subak is an organization owned by the farming community in Bali which specifically regulates the management or irrigation system of rice field used in traditional rice farming. The existence of subak is a manifestation of the Hindu philosophy of Tri Hita Karana (the concept of harmony). Because the role of RFIP for krama subak is very important, hence it is interesting to do research on "Area Mapping and Implementation of Agriculture Insurance in the Organization of Subak in Bali Province". This research aims to find out more about the implementation of RFIP in Subak and krama Subak in Bali Province.
\end{abstract}

\section{KEY WORDS}

Agriculture insurance, mapping area, subak.

Rice is one of the agricultural products which are the most widely consumed food by the Indonesian people compared to other foodstuffs. Based on the 2013 National SocioEconomic Survey data, five foodstuffs with the highest average annual consumption per capita include: rice, sugar, shallots, red chili, and ground coffee. The average per capita consumption of rice in 2013 was $85,514 \mathrm{~kg}$. Meanwhile, the rice field area in 2013 was only 13.77 million hectares with rice production of 70.87 million tons (Insyafiah and Wardhani, 2014).

The high level of national rice consumption is caused by the large population of Indonesia; difficulty of diversification towards other food commodities; people who began to switch to consuming rice as staple food; and the price policy carried out by the Indonesian government on rice commodities. This also caused the open market for rice commodities in Indonesia. The role of rice farming in meeting Indonesia's food needs seems to be accompanied by agricultural characteristics that are prone to risk, thus it is often a threat to the welfare of rice farmers in Indonesia. External factors from the agricultural sector have greater influence than internal factors. For example, anomalies of climate change occurring today, impacted directly on farming activities in Indonesia. Climate change is increasingly unpredictable by farmers, leading to frequent occurrence of events that harm farmers as non- 
optimal or damage to irrigation, farm roads and other agricultural infrastructure (Ramadhana, 2013).

As a precaution against the possibility of crop failure that can occur in paddy rice farming, the government has launched a program of agricultural insurance in several regions in Indonesia that is applied to rice and named Rice Farming Insurance Program (RFIP). Agricultural insurance products are motivated to help farmers bear the risks that arise due to changes in seasonal shifts and loss of agricultural produce. Sources of funding to pay insurance premiums came from government subsidies and farmers, as well as from stateowned companies that cooperate with farmers.

Slightly different from other provinces in Indonesia, RFIP participants in Bali Province are krama subak (subak members) who are members of a subak organization (RFIP participants in other provinces in Indonesia are members of the Farmers Group). Once the role of RFIP is important for krama subak, it is interesting to conduct research on "Mapping Regions and Implementation of Rice Farming Insurance in Bali Province", this research aims to find out more in the implementation and application of RFIP on subak and krama subak in Bali Province.

\section{METHODS OF RESEARCH}

The method of selecting the location of the research was conducted purposively, namely the method of taking the research area by considering the reasons known from the area of the study (Singarimbun, 1991). The use of this method was carried out on the basis of consideration in Bali Province that the RFIP participants in Bali Province were krama subak (subak members) who were members of a subak organization (other Provinces in Indonesia RFIP participants were members of the Farmers Group). After determining the Province of Bali as the location of the study, then Tabanan Regency was chosen as the location of the study with consideration. Tabanan Regency targets the realization of the Rice Farmer Insurance Program (RFIP) to reach 8,000 hectares in 2017 from a total agricultural land area of 21,714 hectares. After determining Tabanan Regency as the location of the study, then Penebel Subdistrict was chosen as the location of the research with consideration, from the realization of the Rice Farmer Insurance Program (RFIP) in Tabanan Subdistrict which reached 8,000 hectares, Penebel Subdistrict received the most allocation compared to other Districts, which is 1,607 hectares. After determining Penebel Sub-district as the location of the study, then three subak were selected to carry out the research, namely Subak Buruan, Penatahan and Keloncing. The three of them were chosen because they have the widest area.

The population in this study were all wetland rice farmers who worked in Penebel Subdistrict. The number of subak samples is three and in each Subak sampled by 20 farmers, thus samples in this study are 60 farmers. Roscoe (1975) in Sekaran (2006) provides a general reference for determining sample sizes of more than 30 and less than 500 is appropriate for most studies.

In this study, data were collected through observation and interviews. The observation technique used was direct observation, observing or seeing, hearing, and feeling the object of the problem under study. Researchers as data collectors were participated and involved in activities that become a source of observation.

Besides being analyzed descriptively, the data was processed with several variations of statistical analysis. For more details, the analysis of each goal is detailed as follows. The first objective is mapping the subak area in Bali Province that has participated in the agricultural insurance program using the on screen digitations method and ground truth check (using ArcGIS software) to the field to produce a map of the research location (Figure 1). The process continued with digitizing all the villages in the entire Tabanan Subdistrict and then entering attribute data from the villages participating in the agricultural insurance program (Figure 2) with the participation period starting in 2016-2018. Furthermore, the process to produce Figure 3 is by entering data on the attributes of the type of funding from the village that follows the insurance, whether the village that participates in insurance uses 
CSR funds or independent funds during the 2016-2018 period. Finally, Figure 4 is produced by choosing the area with Penebel Subdistrict boundary. From all villages in Penebel Subdistrict, then the attribute data of village participation in the agricultural insurance program was added during the 2016-2018 period.

The second objective is to study the implementation of agricultural insurance in Bali Province using descriptive analysis method. This analysis method is used to describe qualitatively the implementation of agricultural insurance in Bali Province, including: (1) background of agricultural insurance, (2) the benefits of agricultural insurance for farmers, (3) the purpose of agricultural insurance, (3) agricultural insurance targets, (4) agricultural insurance model in Bali Province, (5) rice farming insurance, (6) the process of issuing insurance policies and (7) the process of claim settlement. This descriptive analysis method is carried out by means of observation, interviews, and discussions with state-owned enterprises, subak and krama subak.

\section{RESULTS AND DISCUSSION}

This research was conducted in Penebel Subdistrict, by choosing Subak Buruan, Penatahan and Keloncing as samples with the consideration that the three Subak have the largest area compared to other subak in Penebel Subdistrict. Visually in the form of maps can be seen in Figure 1.

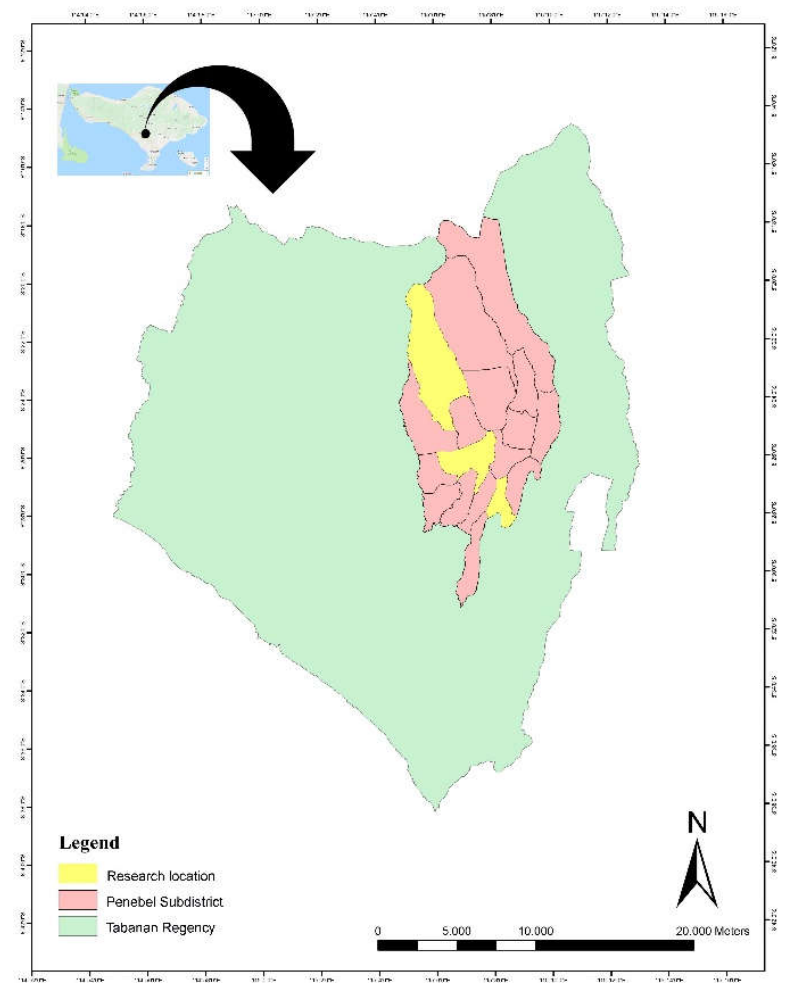

Figure 1 - Map of Research Location

When viewed from the number of participants in agricultural insurance in Tabanan Regency for the period of 2016-2018, the number of Subak participating in the RFIP program is decreasing. Visually in the form of maps can be seen in Figure 2. 

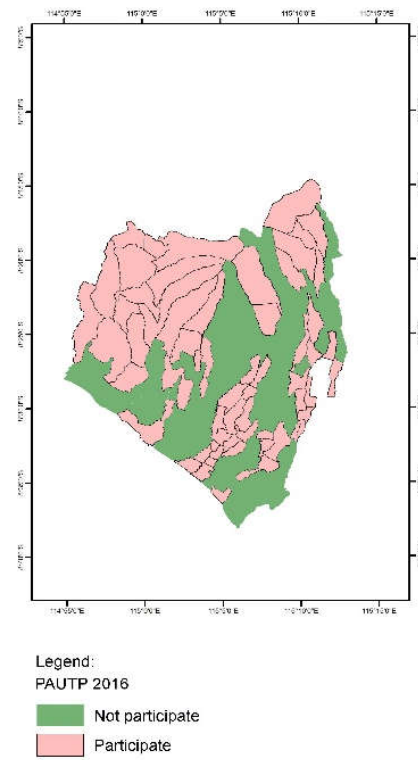

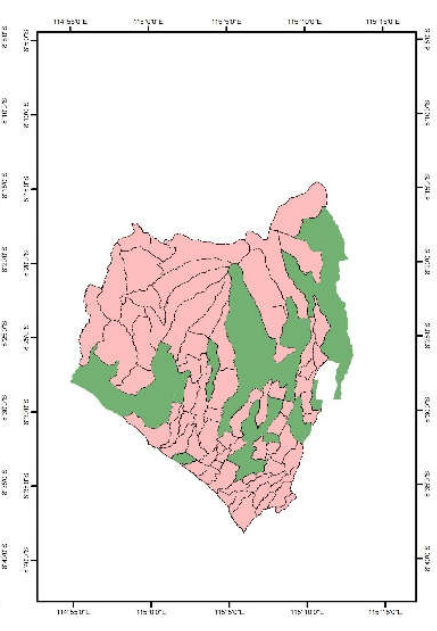

Legend:
PAUTP 2017

Not participate

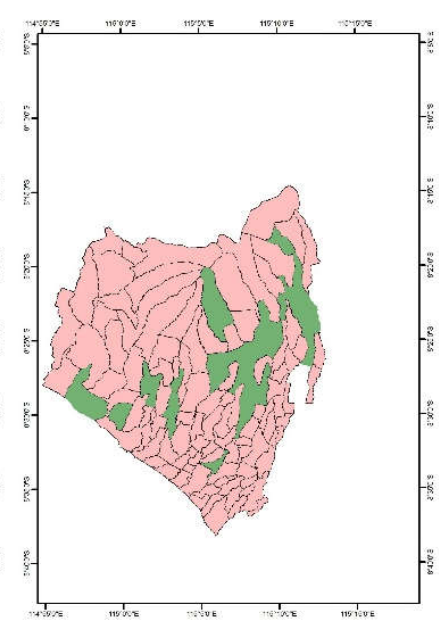

Legend:
PAUTP 2018

Not participate

Participate

Figure 2 - Distribution of Participants in Agricultural Insurance in Tabanan Regency, 2016-2018

When viewed from the total number of agricultural insurance participants in Penebel Subdistrict for the period of 2016-2018, the number of subak participating in the RFIP program has decreased, this is almost the same as the reduced number of subak agriculture insurance participants in Tabanan Regency. Visually in the form of maps can be seen in Figure 3.
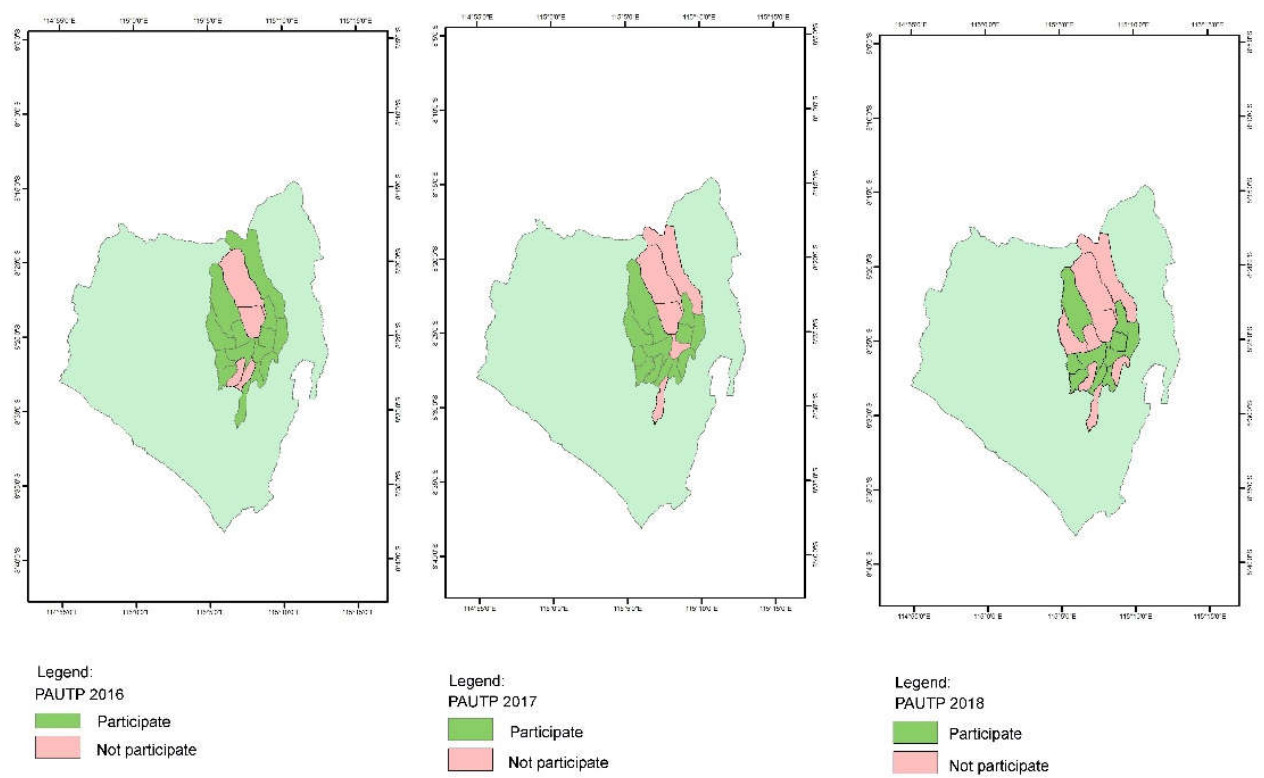

Figure 3 - Distribution of Participants in Agricultural Insurance in Penebel Subdistrict, 2016-2018

When viewed from agricultural insurance participants in Tabanan Regency based on funding sources for the 2016-2018 period, the type of funding that comes from CSR only exists in 2016, whereas in 2017 and 2018 the source of funds for all RFIP participants came from independent funds. Visually in the form of a map can be seen in Figure 4.

Requirements to follow the RFIP up to an explanation of how the process of registering participants, payment of policy issuance and settlement of claims. RFIP socialization was given to prospective RFIP participants. Prospective participants are all farmers who are members of farmer groups in the Province of Bali called Subak and cultivate the types of rice crops. 

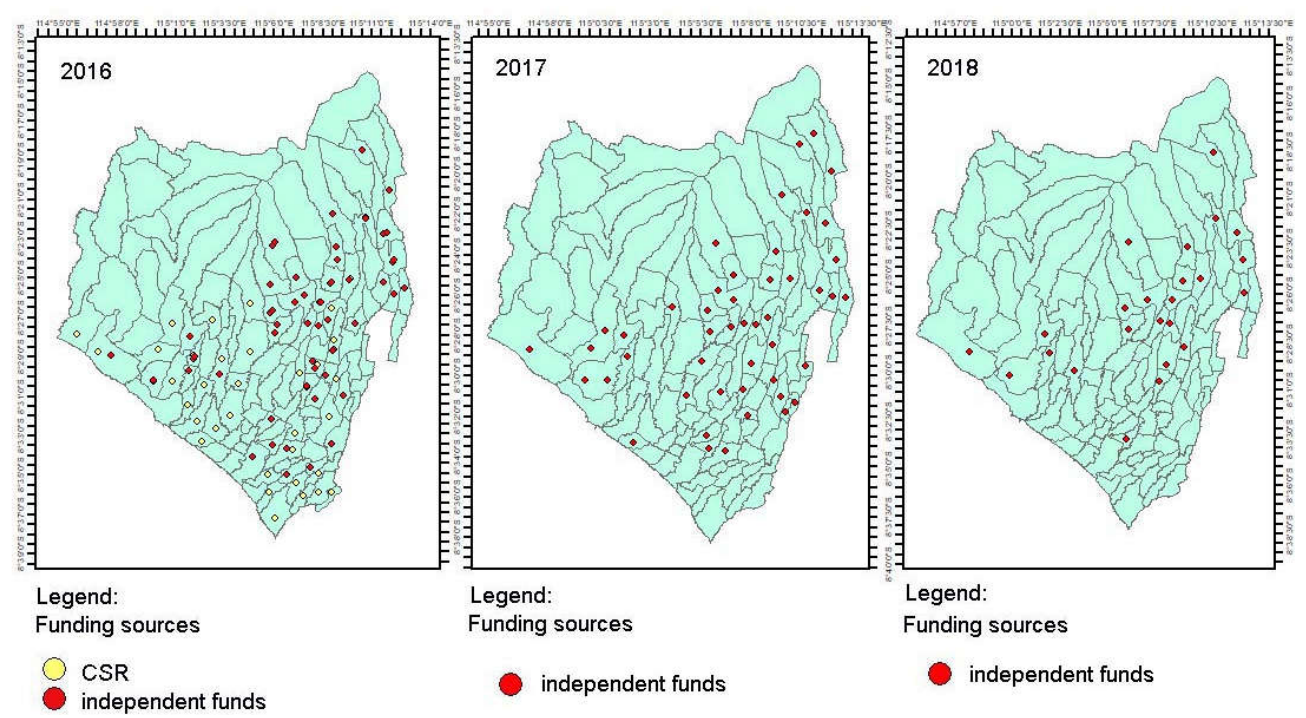

Figure 4 - Distribution of Participants in Agricultural Insurance in Tabanan Regency Based on Funding Sources, 2016-2018

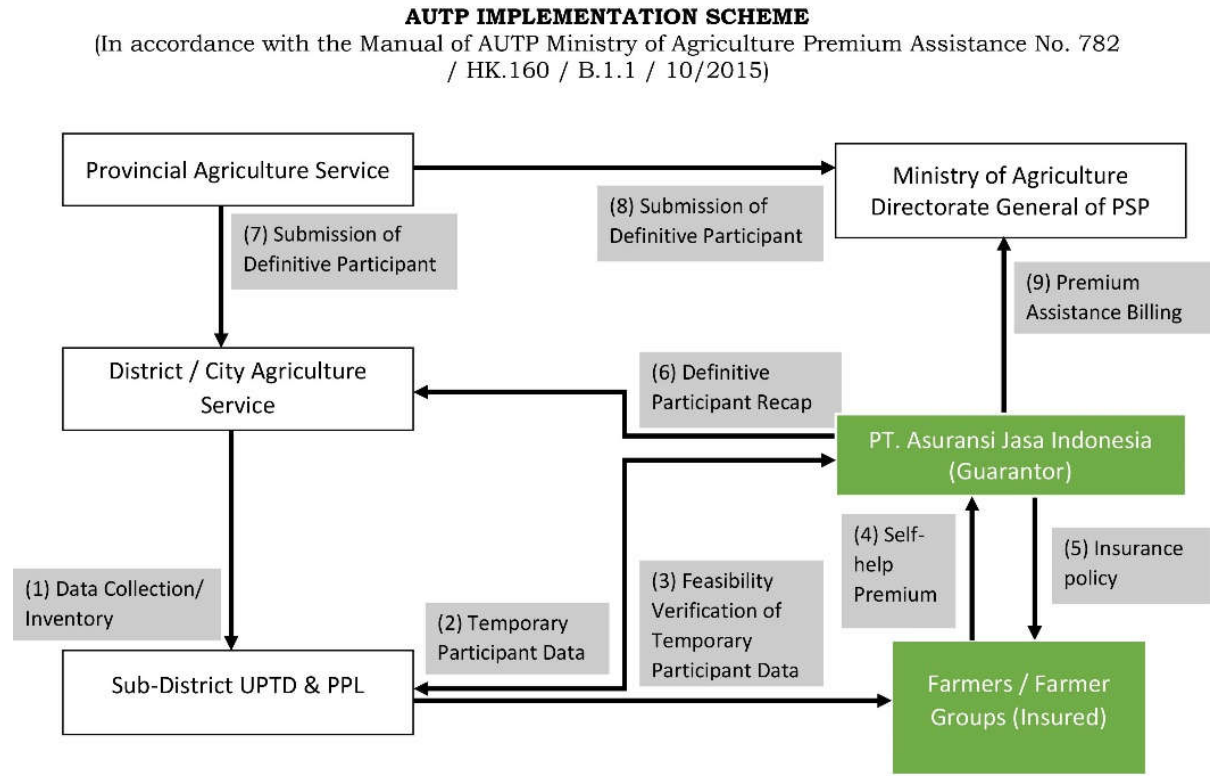

Figure 5 - RFIP Implementation Scheme

The implementation of the RFIP consists of several stages as follows:

- The implementation of RFIP starts from data collection of Prospective Participants Prospective Locations are farmers who are members of farmer / Subak groups using Form 1, namely Data Collection Form for Prospective Participants - Prospective Location of Rice Farming Insurance.

- The next step is the registration process for participants by the farmer groups who take part in the RFIP by filling out the RFIP Participant Registration Form, which includes Form 2 for the insurance, Form 3 for the regional technical implementation unit, Form 4 for the district agriculture office, Form 5 for the Provincial Agriculture Office and Form 6 for the Central Ministry of Agriculture thus a decree can be issued for the disbursement of premium subsidy assistance of $80 \%$ for each farmer, namely IDR 144,000 .

- Form 1 and Form 2 are verified by the local field extension officer by looking at the eligibility of the participant's data such as checking the farmer's land area to match the amount of premium self-help paid by farmers. 
- RFIP participant data that has been verified is immediately paid in self-help premium with a calculation of 1 ha of land paid in premium amounting to IDR36,000 and the premium calculation is proportional to the size of the farmer's rice field and added with IDR144,000 of government subsidies. In the payment process, the regional technical implementation unit is usually the one who contacted PT Jasindo Denpasar Branch to pay the premium.

- The premium is repaid no later than 15 days after the policy is issued. The policy is issued when the RFIP registration file is complete.

- If a claim occurs, the farmer / Subak group fills in Form 7, the Damage Notification Form and Form 8 regarding damage events approved by local field extension officers, coordinator for Plant Disturbing Organism Controllers - Pest and Disease Observers, and the City / District Agriculture Service.

- After the file is complete, the claim process can be completed, but awaiting approval from the insurance and disbursement of funds for claims of farmers from the Ministry of Agriculture Central. After the funds are disbursed, compensation for damaged rice land claims will be given by the insurance to the head of the farmer group. Funds can be in the form of cash or Bilyet Giro (BG).

The process of submitting and disbursing RFIP claim funds takes place every week. Submission of RFIP claim funds is carried out every day depending on whether or not the claim is submitted.

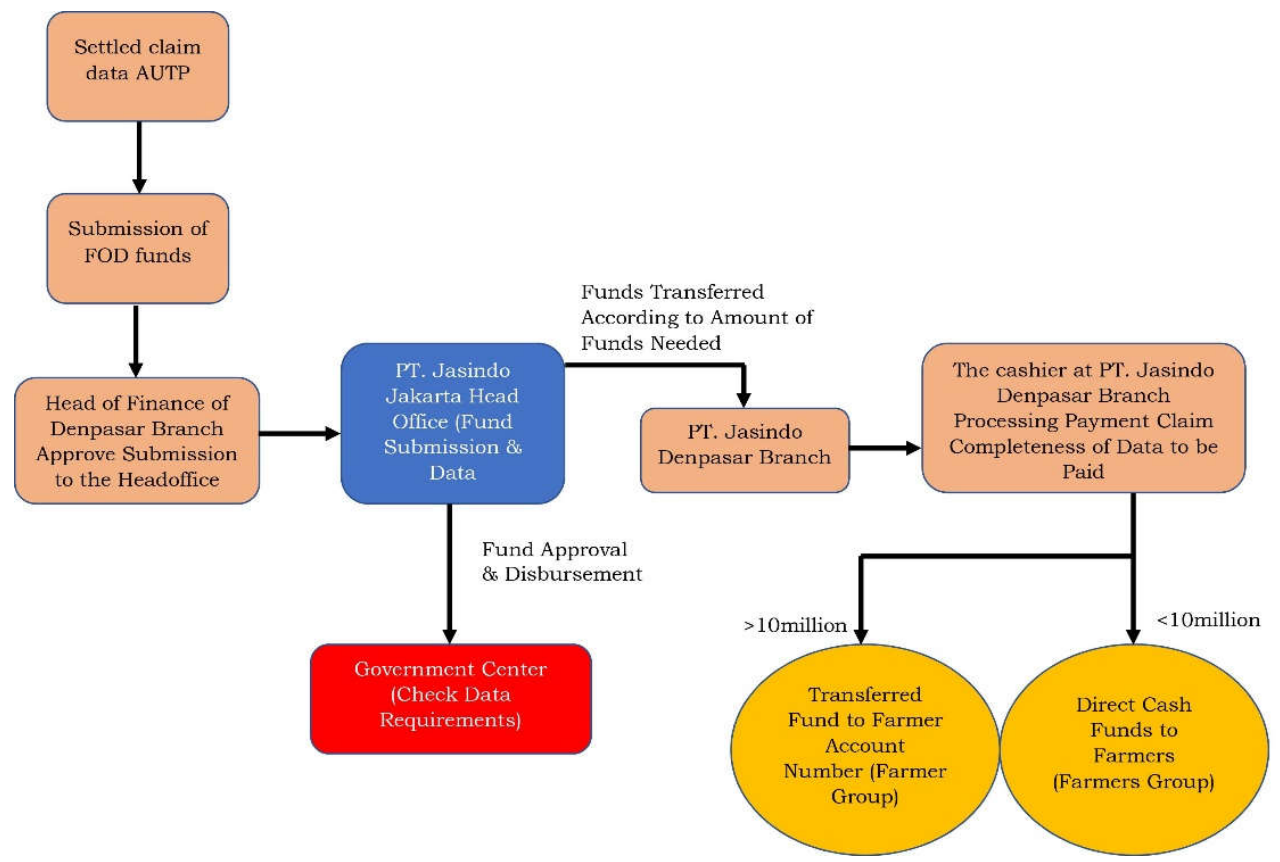

Figure 6 - Submission Process and Fund Disbursement of RFIP Claims at PT Jasindo Denpasar Branch follows:

Figure 6 is the flow or process for submitting and disbursing RFIP claim funds, as

- Settled RFIP claims: The final approval process in the process of making or submitting claims. This process is a claim that has been resolved by Jasindo, the staff serving in the claim section for the next process in applying for funds. If the claim has been settled or resolved, it means that the claim made has actually been in accordance with the data provided by the claimant.

- Submission of bank overdraft (overdraft facility) and non-overdraft facility: funds that will be submitted to the center. The funds proposed are two types of funds, namely bank overdraft and non-overdraft facility. Bank overdraft is the amount of submission of funds that exceeds IDR $200,000,000$ while the non-overdraft facility is the amount 
of fund submission that is less than IDR 200,000,000. Jasindo party, namely the claim administration will submit a proposal for funds that have been detailed to the head of the internal financial unit which will then be processed.

- Head of the Denpasar Branch Financial Unit: In the process of disbursing funds, the Head of the Financial Unit of PT Jasindo Denpasar Branch has the duty to approve or approve the submission of funds that have been settled, either submission of bank overdraft or non-overdraft facility. Without prior approval from the head of the financial unit, funds cannot be submitted to the center (PT Jasindo in Jakarta).

- PT Jasindo Jakarta Center: PT Jasindo Jakarta Center will continue the submission of funds sent by the PT Jasindo Denpasar Branch earlier. PT Jasindo Pusat then submits the proposal to the Government Center.

- Government Center of the Ministry of Agriculture: The submission of funds submitted by PT Jasindo center will be processed in advance by the Government Center of the Ministry of Agriculture whether it has fulfilled the requirements and the data is complete. The data is complete and fulfills the requirements, the government will approve and disburse the funds that have been submitted (funds disbursed by the Government to all PT Jasindo Branches that propose funds). Funds that have been disbursed by the Government were transferred to PT Jasindo Pusat Jakarta. PT Jasindo Pusat has the duty to transfer funds that have been submitted previously by each PT Jasindo Branch to the account number used.

- PT Jasindo Denpasar Branch: PT Jasindo Denpasar Branch receives funds that have been transferred by PT Jasindo Pusat to Bank Mandiri account numbers specifically used by PT Jasindo Denpasar Branch to receive money from the central Jasindo.

- Cashier of PT Jasindo Denpasar Branch: Cashier processes claim payments. The cashier will request data from the administration of the RFIP claim in the form of details of funds that can be paid, receipts and cash loans as proof that the funds have been paid. Then the cashier will transfer funds to the farmer's account number.

- Payment of claim funds to farmers: payment of claim funds can be made by transferring to the bank account number owned by the farmer (if the claim fund payment is more than IDR 10,000,000), and can also be paid directly to farmers or in cash (if the claim payment is less than IDR 10,000,000).

The RFIP premium system is calculated for 1 hectare of rice land, farmers are required to pay a self-help premium of $20 \%$, which is IDR 36,000 and if there is a claim, it will get the compensation that will be obtained for IDR 6,000,000. Such an explanation is considered to be the land insured must be 1 hectare, thus farmers do not join RFIP because they do not have a land area of 1 hectare. Even though the total area of land that you want to insure may be under 1 hectare and a maximum of 2 hectares for each farmer. The following is an example of premium payments with a land area of 50 Are ( 0.5 hectare), as follows:

Total Premium $(1$ hectare $)=$ interest rate of RFIP X Claim Value $(1$ hectare of land area $)=$ IDR 180,000

Thus, for 0.5 hectare of land, farmers only pay IDR 18,000 per planting season.

\section{CONCLUSION}

The RFIP program launched in October 2015 by the Ministry of Agriculture collaborates with Jasindo Insurance and aims to protect farmers from the risks of uncertainty in their farming. Insurance premiums subsidized by the government are $80 \%$ or IDR $144,000 /$ hectare and farmers only need to pay a self-help premium of $20 \%$ or IDR $36,000 /$ hectare of the total premium that must be paid in the amount of IDR 180,000.00/hectare/planting season, if there are no subsidies from the government, thus it is expected that many farmers are interested in participating in insurance. If the farmer has less than two hectares of land, the calculation of premiums and claims is calculated proportionally.

In the process of submitting and disbursing RFIP claim funds, after settled the claim of administration claims will submit a request for funds in the form of a bank overdraft or non- 
bank overdraft to the head of the internal financial unit, then processed to PT Jasindo center in Jakarta and proceed to the government center. After being approved by the government in accordance with the new data, the funds were disbursed to PT Jasindo Jakarta center. PT Jasindo centers to transfer funds that have been submitted to each Jasindo branch. After funds are received at PT Jasindo Denpasar Branch, the funds will be transferred through the Bank to the account number of the farmer according to the claim submitted by them.

\section{REFERENCES}

1. Asuransi Jasa Indonesia, 2015. Annual Report Book, PT Asuransi Jasa Indonesia (Persero). Jakarta.

2. Calkin PH, DiPietre, DD.1983. Farm Business Management Succesful Decisions in Changing Environment. New York: Macmillan Publishing Co. Inc.

3. Fleisher B. 1990. Agricultural Risk Management. London: Lynne Riener Publisher,Inc.

4. Geriya, Wayan., Triguna, IBGY.,Dhana,IN. 1985. Pola Kehidupan Petani Subak Rejasa Di Tabanan. Proyek Penelitian dan Pengkajian Kebudayaan Nusantara (Javanologi) Direktorat Jendral Kebudayaan: Yogyakarta.

5. Harwood J, Heifiner R, Coble K, Perry J, Somwaru A. 1999. Managing Risk in Farming: Concepts, Research and Analysis. Agricultural Economic ReportNo.774. US Department of Agriculture.

6. Hadi, P. U, C. Saleh, A.S. Bagyo, R. Hendayana, Y. Marisa dan I. Sadikin. 2000.Studi Kebutuhan Asuransi Pertanian Pada Pertanian Rakyat. Laporan Hasil Penelitian. Pusat Penelitian Sosial Ekonomi Pertanian, Badan Litbang Pertanian, Departemen Pertanian.

7. Pasaribu, S.M., H.P. Saliem, E. Ariningsih. 2009. Developing agricultural insurancefor rice farming. Final Report of Project CGP/RAS/214/IFA: Pro-Poor Policy Formulation, Dialogue and Implementation At Country Level: Indonesia. Indonesian Center for Agriculture Socio Economic and Policy Studies (ICASEPS) and Food And Agriculture Organization-Regional Asia and ThePacific Office (FAO-RAP), Bogor.

8. Soekartawi. 2003. Agribisnis Teori dan Aplikasinya. PT. Raja Grafindo Persada: Jakarta.

9. Soekartawi. 2005. Prinsip Dasar Ekonomi Pertanian. PT. Raja Grafindo Persada: Jakarta.

10. Soekartawi. 2006. Analisis Usahatani. UI-Press: Jakarta.

11. Subak Sembung. 2014. Eka llikita Subak Sembung Desa Peguyangan. Unpublished: Denpasar.

12. Tenaya, Narka. 2009. Bahan Kuliah Ekonometrika Program Studi Agribisnis.Laboratorium Statistika Fakultas Pertanian Universitas Udayana: Denpasar.

13. W.Windia, IW,Sudana, I Ketut Wirta Griadhi, Sutawan, Nyoman., Ngakan Made Samudra, Suadnya, IGM., I G. Pitana, Nyoman Norken, Ida Bgs. Pt. Purwita, Sushila, Jelantik. 1997. Subak Sistem Irigasi Tradisional Di Bali Sebuah Canangsari. Denpasar: PT Upada Sastra.

14. Windia, Wayan. 2006. Transformasi Sistem Irigasi Subak yang Berlandasankan Konsep Tri Hita Karana. Denpasar: Bali Pustaka.

15. Windia, Wayan., Sudarta, Wayan., Astiti,WS. dkk. 2015. Sistem Subak di Bali (Kajian Sosiologis). Denpasar: Udayana University Press. 